\title{
Chemical analysis and quality assessment of Nigerian indigenous domestic fowl and quail eggs produced at Songhai delta farms
}

Odafe-Shalome, G. I. O. and Owen, E. O. Agro-Foods and Bioresourses Technology laboratory, Department. of Animal Science, Faculty of Agriculture, University of Benin, Benin-City, Nigeria.

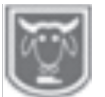

Corresponding author: odafebcn@gmail.com; shalomeodafe@gmail.com;

Abstract gideon.odafe-shlome@uniben.edu; +234(0)8191303319

The quail and indigenous domestic fowl (IDF) are purebred birds that have received little or no genetic manipulation and intensive husbandry in Nigeria. Recently awareness is being created of the potential health value and functional properties of their eggs in industry. This necessitated the interest to examine the indices of egg quality by physical measurements and by chemical analysis of the eggs of the two species. Results showed higher values in IDF eggs for indices of egg size - longitudinal and latitudinal circumference and shell thickness. Weight indices - whole egg weight, albumen weight, and yolk weight, albumen height and yolk height recorded higher values in the IDF eggs. Whole egg weight was $36.51 \pm 3.25 \mathrm{~g}$ for IDF egg, significantly $(p<0.01)$ higher than the whole weight, 9.75 $1.32 \mathrm{~g}$, of quail egg. Also the relative weight (proportion) of shell to total egg weight was higher in the IDF egg $(10.74 \%)$ than in quail egg (9.56\%). However, the proportions of albumen and yolk $(49.38 \%$ and $41.01 \%)$ in quail egg were higher than the corresponding values in IDF egg $(40.59 \%$, and $48.68 \%)$. The Haugh unit HU and yolk index YI values of quail eggs were significantly higher $(P<0.05)$ and $(P<0.01)$ respectively than the values in IDF eggs. The approximate chemical compositions $(\mathrm{g} / 100 \mathrm{gdm})$ of quail eggs were moisture content - 68.12, crude protein-13.45, ether extract-10.45, soluble carbohydrates-4.46, and ash-3.10; whereas IDF eggs measured 71.51, 12.63, 9.74, 3.56 and 2.5 respectively. The differences in crude protein and ether extract values were not significant $(p>0.05)$ for the two sets of eggs.

Keywords: quail, domestic fowl eggs, physical characteristics, chemical composition, quality indices

Une Analyse chimique et évaluation de la qualité des œufs de volaille et de caille domestiques indigènes du Nigéria produits dans les fermes de Songhaï dans l'état de Delta

Odafe -Shalome, G. I. O. and Owen, E. O.

Agro-Foods and Bioresourses Technology laboratory,

Department. of Animal Science, Faculty of Agriculture, University of Benin, Benin-City,

Nigeria.

Corresponding author: odafebcn@gmail.com; shalomeodafe@gmail.com; gideon.odafe-shlome@uniben.edu; +234(0)8191303319

\section{Résumé}

$\overline{\text { La caille et la volaille domestique indigène (le 'IDF') sont des oiseaux de race pure qui ont }}$ subi peu ou pas de manipulation génétique et un élevage intensif au Nigeria. Récemment, on a pris conscience de la valeur potentielle pour la santé et des propriétés fonctionnelles de leurs oufs dans l'industrie. Ceci a nécessité l'intérêt d'examiner les indices de qualité des œufs par des mesures physiques et par analyse chimique des æufs des deux espèces. Les résultats ont montré des valeurs plus élevées dans les æufs 'IDF' pour les indices de taille des 
aufs - circonférence longitudinale et latitudinale et épaisseur de la coquille. Les indices de poids - le poids de l'œuf entier, le poids de l'albumen et le poids du jaune, la hauteur de l'albumen et la hauteur du jaune ont enregistré des valeurs plus élevées dans les oufs 'IDF'. Le poids de l'œuf entier était de 36,51 \pm 3,25 g pour l'ouf de la 'FIL', significativement ( $p$ $<0,01)$ supérieur au poids total, 9,75 $\pm 1,32 \mathrm{~g}$, de l'œuf de caille. De plus, le poids relatif (proportion) de la coquille par rapport au poids total de l'œuf était plus élevé dans l'œuf 'FIL' $(10,74 \%)$ que dans l'ouf de caille (9,56\%). Cependant, les proportions d'albumen et de jaune $(49,38 \%$ et $41,01 \%)$ dans l'ouf de caille étaient supérieures aux valeurs correspondantes dans l'ouf 'IDF' (40,59\% et 48,68\%). Les valeurs de l'unité de Haugh 'HU' et de l'indice du jaune 'YI' des oufs de caille étaient significativement plus élevées $(P<0,05)$ et $(P<0,01)$ respectivement que les valeurs des oufs 'IDF'. 68,12, protéine brute-13,45, extrait d'éther10,45, glucides solubles-4,46 et cendre-3,10; tandis que les oufs du 'FIL' mesuraient respectivement 71,51, 12,63, 9,74, 3,56 et 2,5. Les différences entre les valeurs de protéines brutes et d'extrait d'éther n'étaient pas significatives $(p>0,05)$ pour les deux ensembles d'oeufs.

Mots clés: caille, œufs de volaille domestique, caractéristiques physiques, composition chimique, indices de qualité

\section{Introduction}

The egg is a biological structure intended by nature for reproduction; it serves to protect and provide required nutrient for the developing embryo; and serves as the principal source of nutrient during the first few days of the chick's life (Mizutani, 2003). The egg is also a protein rich food for humans; considered nature most nearly perfect food, as it contains all the essential and required nutrients in appreciable measures, and it is used as reference material in the nutritional and biological evaluation studies (Olomu, 2011). The indices of egg quality are important in nutrition and in Food process industry. There seem to be similarities in nutrient composition and potential food value of the eggs of many species of birds. However, information on quality, storage characteristics and utilization of the eggs is limited except those of improved breeds of the domestic fowl. The reason for this is because researchers tend to place more emphasis on the products of the improved domestic fowl (chicken), and less on other poultry species. There seem to be a diminishing interest to produce the eggs of other poultry species, particularly the indigenous domestic fowl and the quail for nutritional purpose. The quail is a less conventional bird in Nigeria. As with the indigenous domestic fowl, quail eggs have not been extensively researched; although there are indications that quail egg provides numerous nutritional and health benefits (Tunsaringkarim et al., 2013; Sahin et al., 2018). There is an increasing awareness of the importance of quails and quail eggs in Nigeria. Hence there is evidently the need to provide information on their acceptance value. There is also a need to have update information and understanding of the characteristics and potential value of the eggs of the pure breed, indigenous domestic fowl [IDF]. This study sought to examine the quality characteristics and chemical composition of quail eggs and indigenous domestic fowl eggs, both of which have not been subjected to intensive genetic manipulation. The objectives were to examine the external and internal characteristics of the eggs, compare their observable and measurable characteristics, and determine by chemical analysis, their proximate compositions with reference to whole hens egg. 


\section{Odafe-Shalome and Owen}

\section{Materials and methods}

\section{Study location and materials}

Quail eggs are produced in the quail unit in Songhai-Delta Demonstration Farm, located at Amukpe, Sapele. Proximal to that farm is the Poultry Market in Sapele, where all species of poultry and game birds, including quails and the indigenous domestic fowl (IDF) and their eggs are sold to consumers. Both sites are located about $60 \mathrm{~km}$ from Benin-City, where laboratory work was undertaken during this study. All the locations lie within latitude $6^{\circ} \mathrm{N}$ and $30^{\circ} \mathrm{N}$ and longitude $6.35^{\circ} \mathrm{E}$, in the rain forest vegetation belt of Southern Nigeria. Daily temperature range $23.0^{\circ} \mathrm{C}-27.6^{\circ} \mathrm{C}$; average annual rainfall $2000 \mathrm{~mm}$; and a mean relative humidity of $72.5-95.0 \%$.

\section{Quail eggs and Indigenous fowl eggs}

Two different crates of eggs, one contains a total of thirty (30) freshly laid quail eggs of averagely equal size and the other thirty (30) IDF eggs were purchased from the Songhai farm shop. The eggs were transported in crates to the food process laboratory, faculty of Agriculture, University of Benin in Benin-City, for measurements and analyses. Egg quality parameters including external and internal characteristics were examined for each of the thirty eggs in the crates. The characteristics measured included the wholesomeness, freshness, egg size and weight, shell quality, yolk index, albumen index, haugh unit and chemical composition which affect consumer acceptance and utilization.

\section{Physical measurements}

Egg size was determined by measuring the longitudinal and latitudinal axes of the egg using the veneer caliper. Their corresponding circumferences were measured by using a piece of thread to circle round the length and breadth of the egg and then stenciling the distance covered on a meter rule. Egg weight was measured on Electronic balance (Mettler model PC
2000) sensitivity 0.01g. Shell Surface Area (SSA) was calculated using the mathematical equation expressed by Carter (1975) as follows: SSA $=3.9782 \mathrm{x}$ SW0.7062; where SW = shell weight. Shell weight was determined by breaking the egg gently using a scalpel. The egg albumen and yolk were gently separated from shell. Then egg shell was labeled and dried under fan; and then shell weight was estimated using the Mettler Electronic balance. Shell thickness was obtained from samples of dried egg shell using mini micrometer screw gauge and mean values were obtained for each egg examined. Albumen index was obtained by weighing the egg and separating the shell and the content. Egg content was carefully discharged unto a petri-dish placed on a smooth concrete table, ensuring that albumen and yolk were intact and not agitated. With the aid of an automated veneer caliper, the height of the thick albumen was determined as distance of surface from chalaza located at a point midway between the inner and outer edges of the thick white. Thereafter yolk diameter was measured. The values were used in calculating the albumen index, which is a ratio obtained according to the following formula: Height of thick albumen (mm) / Average diameter of yolk $(\mathrm{mm})$

For Yolk Index the diameter and height of the yolk were measured with the aid of a veneer caliper without the yolk being separated from the albumen. The yolk index (YI) was thus computed as the ratio of yolk height to yolk diameter using the formula:

$$
\mathrm{YI}=\text { Height of yolk }(\mathrm{mm}) /
$$

Average diameter of yolk (mm).

Yolk weight was obtained by separating yolk from the albumen and weighed. The weight of the albumen was obtained by difference. The weight of the yolk and albumen were then expressed as a percentage of the eggs contents. Haugh unit (HU) was calculated from the values of 
albumen height $(\mathrm{H})$, the egg weight $(\mathrm{W})$ and gravitational constant (G) using the standard equation advanced by Haugh (1937):

$\left.\left(30 \mathrm{~W}^{037}-100\right) / 100+1.9\right]$

$$
\mathrm{HU}=100 \log \left[\mathrm{H}-\mathrm{G}^{05}\right.
$$

\section{Chemical analyses}

Proximate Analysis was performed for crude protein, crude fiber, moisture, ash, fat and soluble carbohydrates, nitrogenfree-extract, using standard analytical methods (AOAC, 2010).

\section{Dry Matter and Moisture Content}

A number of crucibles were oven dried, cooled in dessicator and then weighed, using a Contech electronic balance, model CB-50. After weighing, each whole egg was broken to allow for separation of shell and egg content (the albumen and yolk). The egg content was discharged into the previously weighed crucible and then weight of crucible plus content was taken and recorded. The weight of the albumen together with yolk was thus obtained by difference. The crucibles with their contents were later transferred into a Thermostat Drying Oven, model DHG9202, to dry the samples at temperature set at $100^{\circ} \mathrm{C}$ for $16-18$ hours. It was necessary to ensure that all free moisture escape from the sample, by weighing, reheating and reweighing to until constant weight was achieved. Thus, repeatedly, sample crucibles were removed from oven, dessicated and cooled, weighed and then recycled through the stages, during the set time. Dry matter (DM) and moisture content (MC) of egg sample were thus computed as follows:

$$
\%(\mathrm{MC})=[\mathrm{Ws}-\mathrm{Wb} / \mathrm{Wa}] \times 100 \%
$$

$(\mathrm{DM})=100-\%$ moisture

Ws- weight of sample taken. Wb- weight of

sample + weight of crucible before drying. Wa-

weight of sample + weight of crucible after

Crude protein drying.

The crude protein in a sample was calculated from the nitrogen present in the protein which was determined by the conventional kjedhal procedure. Two gram (2g) portions of each egg sample was weighed and transferred into a Kjedhal round bottom flask. An amount $(20 \mathrm{ml})$ of conc. sulphuric acid (H2SO4) and $1 \mathrm{~g}$ of selenium catalyst were measured into the flask. The flask was placed in digestion system and heated until the solution became colorless. The process converted the nitrogen present in sample to ammonia in the form of ammonium sulphate. Following digestion, flask was removed from heating module and cooled. Then the ammonia was liberated by distillation, using the Tecator Nitrogen Analyzer fitted with provisions for adding sodium hydroxide $(\mathrm{NaOH})$ to the digest to distil off the $\mathrm{NH} 3$ from the digest, and then collected into boric acid $(5 \mathrm{ml})$ and thereby distillate was titrated. The crude protein was calculated on the basis that the nitrogen content of protein is $16 \%$. The nitrogen content was thus multiplied by factor 6.25, to obtain sample protein content according to the following equations and calculations:

Stage 1:

$\left(-\mathrm{Nh}_{2}\right)+\mathrm{H}_{2} \mathrm{SO}_{4}-\left(\mathrm{NH}_{4}\right)_{2} \mathrm{SO}_{4}+\mathrm{CO}_{2}+\mathrm{O}_{2}$ Stage 2:

$\left(\mathrm{NH}_{4}\right)_{2} \mathrm{SO}_{4}+\mathrm{NaOH}-\mathrm{NaSO}_{4}+2 \mathrm{NaH}_{3}+\mathrm{H}_{2} \mathrm{O}$

$\%$ Nitrogen was calculated as: $\% \mathrm{~N}=[\mathrm{VAx}$ $\mathrm{VF} / \mathrm{Ws} \mathrm{x}$ aliquot $] \mathrm{x}\left[\mathrm{MW}_{\mathrm{N}} / 100\right] . \% C P=$ $\% N \times 6.25$.

where VA - initial volume of acid used, VF- volume of volumetric flask used for digestion.

$\mathrm{MW}_{\mathrm{N}}-$ molecular weight of nitrogen (0.00014) Ws - weight of sample.

\section{Ash content}

A quantity (2g) of each egg sample was measured into a previously weighed and ignited crucible; the crucible with sample was then transferred to a Gallenkamp muffle furnace Size2; set at $500^{\circ} \mathrm{C}$ for 6 hours until the ash (grey white) color was 


\section{Odafe-Shalome and Owen}

observed, indicating that the organic matter had been ignited. Following removal of crucible from furnace, the residue (ash) was cooled in a dessicator and weighed. The ash content was thus expressed according to the equation:

\section{weight of sample] x 100}

$\%$ Ash $=$ [weight of ash /

\section{Ether extract}

Fats and fatty substances are characterized by their solubility in the series of organic solvents and this phenomenon was utilized in determining the lipid content of the egg samples. Crude lipid was determined by extracting $5 \mathrm{~g}$ of each sample with petroleum ether using soxhlet extraction system. The Socet equipment model 520 with heating module, condenser and evaporation systems was used. Following extraction, the solvent was distilled off and the residue was dried in a Lilley vacuum oven set at $72^{\circ} \mathrm{C}$, for 90 mins. Thereafter, residue was dessicated and cooled and then finally reweighed. The drying and weighing procedure was repeated severally until a constant weight was obtained. From the initial weight of the sample, the proportion of crude lipid in the dry matter was calculated according to standard equation thus:

\section{/ weight of sample] x100}

$$
\% \text { Ether extract }=[\text { weight of oil }
$$

\section{Nitrogen free extract}

The Nitrogen Free Extract (NFE) represents the soluble carbohydrates present the egg samples; and was determined by computing the difference between the sum of all other proximate components - ash, crude protein and fat - in the sample and the number 100 , representing the relative sum of approximate components:

$$
\% \mathrm{NFE}=\% \mathrm{DM}-\%(\mathrm{CP}
$$

+ Ash + EE).

\section{Statistical analysis}

Variance analysis was performed for the data collected from the different determinations and means were separated by species and compared by Duncan's Multiple Range Test.

\section{Results \\ External quality characteristics of quail and IDF eggs}

The eggs of indigenous domestic fowl IDF and Quails, have similar shapes (Table 1). Both types of egg exhibited oval conical shape with blunt and pointed ends; and with little differences between them. Egg color for IDF was white-light brown; while for quail egg color was sandy-brown dotted with dark brown specks and patches. Egg size was determined by measuring the lengths, and circumferences of the eggs. The results showed that IDF egg recorded significantly higher $(\mathrm{P}<0.01)$ values, than quail egg, in all the parameters measured for size (Table1). Also the IDF eggs recorded egg weight which was significantly higher $(\mathrm{P}<.0 .01)$ than weight of quail egg. The average weight ( $g$ ) of IDF egg was $36.52 \pm 3.25$ whereas mean weight of quail egg was $9.75 \pm 1.32$ (Table1). The shell weight of the IDF egg recorded $3.59 \mathrm{~g}$, which was highly significant $(\mathrm{P}<0.01)$, four times higher than the shell weight $(0.85 \mathrm{~g})$ of quail egg. The shell surface area of the IDF egg also recorded a significantly higher value $(\mathrm{P}<0.01)$, more than twice the value for quail egg. Also the egg shell thickness of IDF egg was significantly higher $(\mathrm{P}<.0 .01)$ than shell thickness of quail egg $(0.20 \pm 0.05 \mathrm{~mm})$. 
Chemical analysis and quality assessment of Nigerian indigenous domestic fowl and quail eggs

Table 1: Physical characteristics of the eggs of quail and indigenous domestic fowl

\begin{tabular}{lll}
\hline Parameter & Quail & Domestic fowl \\
\hline Egg weight $(\mathrm{g})$ & $9.75 \pm 1.32^{\mathrm{d}}$ & $36.51 \pm 3.25$ \\
Longcircumferencen $(\mathrm{cm})$ & $8.87 \pm 0.33^{\mathrm{C}}$ & $14.43 \pm 0.38$ \\
Latitudinal circumference $(\mathrm{cm})$ & $7.88 \pm 0.3 \mathfrak{F}^{\mathrm{C}}$ & $12.71 \pm 0.93$ \\
Egg length $(\mathrm{mm})$ & $29.55 \pm 1.9^{\mathrm{d}}$ & $50.44 \pm 1.375$ \\
\hline
\end{tabular}

$\mathrm{a}, \mathrm{b}, \mathrm{c}$, Means in the same row not sharing the same subscript differ significantly $(\mathrm{P}<0.05)$

Internal quality characteristics of quail and IDF eggs

For IDF eggs albumen weight (AW) and yolk weight $(\mathrm{YW})$ were $17.79 \mathrm{~g}$ and $14.74 \mathrm{~g}$ respectively, whereas albumen height $(\mathrm{AH})$ and yolk height $(\mathrm{YH})$ measured $6.38 \mathrm{~mm}$ and $10.53 \mathrm{~mm}$ respectively. The corresponding measurements for quail eggs were $4.78 \mathrm{~g}$ and $3.97 \mathrm{~g}$ AW and $\mathrm{YW}$ respectively, $4.00 \mathrm{~mm}$ and $9.62 \mathrm{~mm} \mathrm{AH}$ and
YH respectively (Table 2). For each of the quality indices IDF eggs measured significantly $(\mathrm{P}<0.05)$ higher value than quail eggs. However, the computed values of albumen index (AI) and Haugh unit (HU) of quail egg were significantly higher $(\mathrm{P}<0.05)$ than values obtained for IDF egg. The yolk index (YI) of the quail egg was most significantly higher $(\mathrm{P}<0.01)$ than indigenous domestic fowl egg (Table 2).

Table 2: Physical composition of the eggs of quail and Indigenous domestic fowl

\begin{tabular}{lll}
\hline Parameters & Quail eggs & IDF eggs \\
\hline Albumen weight $(\mathrm{g})$ & $4.78 \pm 0.70^{\mathrm{a}}$ & $17.79 \pm 1.7 \mathrm{~s}$ \\
Albumen height $(\mathrm{mm})$ & $4.00 \pm 0.26$ & $6.38 \pm 0.27^{\mathrm{b}}$ \\
Albumen index & $0.16 \pm 0.00^{\mathrm{a}}$ & $0.15 \pm 0.0 \mathrm{P}$ \\
Yolk weight $(\mathrm{g})$ & $3.97 \pm 0.58^{\mathrm{a}}$ & $14.75 \pm 1.4 \mathrm{\phi}$ \\
Yolk height $(\mathrm{mm})$ & $9.62 \pm 0.37$ & $10.53 \pm 0.39$ \\
Yolk index & $0.39 \pm 0.02^{\mathrm{a}}$ & $0.25 \pm 0.01^{\mathrm{b}}$ \\
Haugh unit & $82.84 \pm 2.93$ & $78.06 \pm 1.79$ \\
Shell surface area (emm & $3.54 \pm 0.3 \mathrm{P}$ & $9.80 \pm 0.6 \mathrm{7}$ \\
Shell thickness $(\mathrm{mm})$ & $0.20 \pm 0.05^{\mathrm{a}}$ & $0.46 \pm 0.02$ \\
Shell membrane $(\mathrm{mm})$ & $0.05 \pm 0.0 \mathrm{P}$ & $0.06 \pm 0.01$ \\
Shell weight & $0.85 \pm 0.10^{\mathrm{a}}$ & $3.59 \pm 0.58$ \\
\hline
\end{tabular}

$\mathrm{a}, \mathrm{b}, \mathrm{c}$, Means in same row with different subscript differ significantly $(\mathrm{P}<0.05)$

\section{Relative weights of egg components}

The relative weights - the proportion of eggshell, yolk, and albumen, in relation to whole egg are as shown in Table3. The relative weight (RW) of egg shell measured for domestic fowl was higher non- significantly $(\mathrm{P}>0.05)$ than the RW of quail egg shell. Conversely the relative weights of yolk and of the albumen recorded for quail eggs were non-significantly higher $(\mathrm{P}>0.05)$ than values measured in IDF egg (Table 3).

Table 3: Relative weight of structural components of whole eggs of quail and IDF

\begin{tabular}{llll}
\hline Species & Yolk & Albumen & Eggshell \\
\hline Quail & $41.21^{\mathrm{a}}$ & $49.38^{\mathrm{b}}$ & $8.78^{\mathrm{C}}$ \\
Indigenous Domestic fowl & $40.59^{\mathrm{a}}$ & $48.68^{\mathrm{b}}$ & $9.86^{\mathrm{C}}$ \\
\hline
\end{tabular}

$\mathrm{a}, \mathrm{b}, \mathrm{c}$, Means with same superscript in same column are not significantly $(\mathrm{P}>.0 .05)$ different 


\section{Odafe-Shalome and Owen}

\section{Chemical composition of quail and IDF eggs}

The results of proximate analyses indicate that both species have similar pattern of composition and distribution and of main nutrient components - moisture, protein, fat (lipids), nitrogen-free extract (carbohydrates) and ash (minerals) in their eggs (Table 4). Moisture content value was higher in IDF egg; whereas Quail egg recorded higher concentrations of protein, lipid, carbohydrates, and ash than IDF egg. Differences between the different components were not significant $(\mathrm{P}>0.05)$.

Table 4: Chemical composition whole egg of quail and IDF (g/100g) fresh weight

\begin{tabular}{llllll}
\hline Species & Moisture & Protein & Lipid & NFE & Ash \\
\hline Quail & $68.12^{\mathrm{a}}$ & $13.45^{\mathrm{b}}$ & $10.45^{\mathrm{C}}$ & $4.46^{\mathrm{d}}$ & $3.10^{\mathrm{e}}$ \\
IDF & $71.51^{\mathrm{a}}$ & $12.63^{\mathrm{b}}$ & $9.74^{\mathrm{C}}$ & $3.56^{\mathrm{d}}$ & $2.56^{\mathrm{e}}$ \\
\hline
\end{tabular}

$\mathrm{a}, \mathrm{b}, \mathrm{c}$, Means with same superscript in same column are not significantly $(\mathrm{P}>.0 .05)$ different

\section{Discussion}

\section{Quality of IDF and quail eggs}

Egg quality is defined by the egg's external and internal characteristics, which are the factors that determine its food and economic value and its acceptability to consumers (De Ketelaere et al., 2004). The external quality characteristics include cleanliness, freshness, egg size and weight, egg shell color and shell consistency (Narushin and Romnov 2002; Dunn et al., 2005). Those characteristics, being external, are observable; and hence determine the market value of the egg. The internal characteristics include the albumen and yolk indices, the haugh unit, and chemical composition of the egg; which are only measurable following recommended procedures (Keener et al., 2006). Generally, the internal characteristics are influenced by management and genetic factors in poultry production (Egahi et al., 2013); and they are the chief determinants of the quality of egg and egg products (liquid egg, frozen egg, egg powder and yolk oil) from food process industry (Silversides and Budgell, 2001). The eggs of two common, but lesser known poultry species, indigenous domestic fowl IDF and Quails, were examined for their quality (Tables 1$3)$. The eggs exhibited oval conical shape with blunt and pointed ends; and with little differences between them. Egg size was an observable quality, but also measurable; and could be defined by the latitudinal and longitudinal lengths and circumferences of an egg. Expectedly, the results showed that IDF egg was bigger in size, recorded significantly higher $(\mathrm{P}<0.01)$ values than quail egg in all the parameters of size measured (Table1). Also the IDF eggs recorded average egg weight of about $37 \mathrm{~g}$, which was significantly higher $(\mathrm{P}<.0 .01)$ than the average weight of quail egg, which was approximately $10 \mathrm{~g}$ (Table 1 ). It was computed that the average weight of a quail egg is about $8 \%$ of the hen's bodyweight (Shim kimfah, 2005). In comparison, the average weight of chicken egg, about $65 \mathrm{~g}$, is approximately $3 \%$ of the hen's body weight; while turkey egg weighing about $120 \mathrm{~g}$, is $1 \%$ of turkey hen bodyweight (Rankling et al, 1998; Shim kimfah 2005). This implies that creation naturally designed quails for egg production. Elsewhere studies indicate that dressing percentage is relatively low, producing internal and external offals which are proportionately higher than the lean and bone derived from slaughter (Odafe and Uwadia, 2020). On the other hand, and in support of that inference is the fact that a laying quail hen, is highly prolific, reaching point of lay at 6 weeks, and producing about 
300 eggs in a year for about 3years (Mizutani, 2003). Therefore, it can be deduced that like layers, such as hubbard golden commet, and unlike other birds in commercial farming, eggs are the primary products of quails. The shell surface area measured for IDF egg was significantly $(\mathrm{P}<0.01)$ greater than twice surface area measured for quail egg. Egg color for IDF was white or light brown; while for quail egg color was sandy-brown dotted with dark brown colored specks and patches. The indices of shell quality include shell color. This corroborates other reported studies indicating that whereas IDF eggs are either white or light brown, Quail eggs are characterized by a variety of color patterns; which range from snow white to completely brown; and more commonly tan and dark brown, speckled or mottled brown with a chalky blue shells (Randall and Bolla, 2008). The shell thickness of quail egg was $0.20 \mathrm{~mm}$. This value is the equivalence of $0.197 \mathrm{~mm}$ earlier reported by Randall and Bolla (2008). For indigenous domestic fowl the egg shell thickness was significantly higher $(\mathrm{P}<.0 .01)$, about 2.5 times as thick as the value of quail egg shell. The egg shell is a very important structure, enclosing other functional components of the eggs. The integrity of the egg shell is critical for the egg to maintain its quality. Eggs deteriorate in internal quality with time and the rate of deterioration is dependent on the quality of the shell. The internal contents are well preserved in storage when shell structure and consistency are maintained (Jones et al., 2005; 2007). Evidently poor storage conditions could adversely affect shell quality resulting in shell porosity or breakage and of spoilage of internal contents, which implies loss of egg quality and market value (Kirindu and McKee, 2000; Jones et al, 2005; 2007). The relative weights (RW) of main structural components i.e. the proportion of eggshell, yolk, and albumen, in relation to the total weight of whole egg indicate a semblance between the two species of birds. Whereas the mean weight of the IDF egg (37g) and quail egg (10g) were significantly different $(\mathrm{P}<.0 .01)$, the patterns of relative weights of the structural components were similar between the two sets of eggs (Table 3); notwithstanding that IDF eggs recorded whole egg weight which was significantly higher than weight of quail egg (Table 1). The relative weight (RW) of egg shell of domestic fowl was higher non-significantly $(\mathrm{P}>0.05)$ than the RW of shell of quail egg; whereas the shell weight of the indigenous domestic fowl egg was found to be significantly higher $(\mathrm{P}<0.01)$ weighing $3.59 \mathrm{~g}$, which is four times more than the shell weight $(0.85 \mathrm{~g})$ of quail egg. Conversely the relative weights of yolk and of the albumen recorded non-significantly higher $(\mathrm{P}>0.05)$ values for quail eggs than IDF egg (Table 3$)$. The significance of these measurements lies in the fact that the average weights of yolk, egg, and shell vary in relation to position of the egg in egg laying sequences of the quail hen; there were reported studies that the first coturnix egg of a laying sequence is smaller than succeeding eggs in the sequence, whereas that was in contrast with the laying sequence for domestic fowl and turkey hens (Woodward et al., 1975). This study recorded a higher proportion of yolk and albumen in quail egg corroborating the findings of Sahin et al. (2008). Each of the quality factors - albumen weight (AW), albumen height $(\mathrm{AH})$, yolk weight (YW) and yolk height (YH) - was significantly different between the two sets of eggs (Table 2). IDF eggs measured significantly $(\mathrm{P}<0.05)$ higher values than quail eggs. However, the albumen index (AI), yolk index (YI), and the Haugh unit (HU) of quail egg were conversely significantly higher $(\mathrm{P}<0.05)$ than corresponding index values in IDF egg. Of interest, the yolk 


\section{Odafe-Shalome and Owen}

index of quail egg was significantly higher $(\mathrm{P}<0.01)$ than indigenous domestic fowl egg (Table 2). Data analysis indicates that there was a significant difference $(\mathrm{P}<0.05)$ in the Haugh unit (HU) of quail eggs and the HU of IDF egg (Table 3). The lower values of the yolk index (YI) and haugh unit of the indigenous domestic fowl, we observed in this study may arguably, be attributed by some researchers to the production and marketing system of the IDF egg, the storage conditions at the local market and/or the poor record keeping of the age of the birds by the farmers (Coutts and Wilson, 1990; Olomu, 2011). However, the eggs examined in this study were products from Songhai delta demonstration farm wherein standard husbandry techniques and model farm practices were evident. Genetic factors could thus be an alternative explanation, in support of previous suggestions (Sakunthaladevi and Reddy, 2004; Egahi et al., 2013).

\section{Chemical composition of quail and IDF eggs}

Quail egg contained higher concentrations of protein, lipid, carbohydrates, and ash than IDF egg; (Table 4) but the differences were not significant $(\mathrm{P}>0.05)$. However this study revealed that the two sets of eggs have similar patterns in chemical composition and distribution and of main nutrient groups. There is therefore the possibility that IDF egg may also have certain properties which have been ascribed to quail eggs. There are indications that many positive attributes have been assigned to quail egg. The whole hens egg of the domestic fowl is considered nature's nearly most perfect (complete) food, containing virtually all essential nutrients and responsible for the embryological development of the different histological and structural components of the animal (Olomu, 2011). Similarly, quail egg is considered a health and functional food; it has a nutritional value which is reportedly about four times greater than chicken eggs (Tunsaringkarn et al, 2013). The proximate chemical composition of the quails examined in this study were similar to published data which indicate that an average whole quail hen's egg weighing about 10 grams, contains 158 calories of energy, $74.6 \%$ water, $13.1 \%$ protein, $11.2 \%$ fat and $1.1 \%$ total ash (Shim kimfah, 2005) The minerals reportedly present include $0.59 \mathrm{mg} \mathrm{Ca}, 220 \mathrm{mg} \mathrm{P}$ and $3.8 \mathrm{mg} \mathrm{Fe}$. In addition there were about $300 \mathrm{iu}$ vit $\mathrm{A}$, $0.12 \mathrm{mg}$ vit $\mathrm{B} 1,0.85 \mathrm{mg}$ vit $\mathrm{B} 2$ and $0.10 \mathrm{mg}$ nicotinic acid in addition to a rich content of vitamin D and antioxidants. (Shim kimfah, 2005; Olomu, 2011). Hence quail egg is harnessed in food industry to improve quality and functional properties of processed foods, color, oxidative stability, tenderness and storage properties of foods derived or originating from animals (Coutts and Wilson, 1990; Bain, 2005).

In nutritional and health therapeutics quail egg has been, reportedly exploited as an adjuvant in the management of stress related debilitating health conditions, including hypertension, digestive disturbance, gastric ulcer, liver problems, blood pressure and lipids, migraine, asthma, anemia, eczema, heart problems, bronchitis, depression, panic attacks, anxiety and various types of allergies (Tunsaringkarim et al., 2013; Sahin et al., 2018). The health promoting properties of quail eggs include those related to growth stimulation, increase in libido and sexual function, stimulating brain functions, improving intelligence and ensuring stability of processes in human body (Sahin, et al., 2008). Hence the consumption of quail eggs is recommended for children and for pregnant and lactating women as well as for patients in surgery and radiotherapy. Besides supporting life during embryonic growth, hen's egg and component parts are useful as unique sources of animal protein in human 
nutrition (Silversides and Budgell, 2001). Nutritionists consider the whole hens egg (WHE) as the universal reference protein, assigned a chemical score of 100 and used as standard in the evaluation of protein of other feeding stuff (Olomu, 2011). Following the recent trend, awareness of quail farming is on the increase; and quail egg is steadily becoming a popular protein source. In comparison, the indigenous domestic fowl is still consigned to being a free-range, low scale rural concern without aim of commercialization (Oluwatade et al., 2009); and this is not unconnected with advances in the production and productivity of improved breeds of the domestic fowls broilers and layers. However, the indigenous domestic fowl, like the quail, is pure breed and native with traits which are genetically inherent and functional properties of its meat and egg still intact (Horst, 1991; Ajayi, 2010; Dana et al, 2011). Thus current food programs are aimed at encouraging the development of functional foods, including suggestions to develop village poultry as a means of mitigating infectious diseases prevalent globally (Tunsaringkarn et al., 2013). This calls for the research exploits into the functional properties of native species and their natural and primary products, such as the IDF egg. In this study comparative analysis indicates that except in egg size there is a semblance between the IDF egg and quail egg in most physical and chemical characteristics; therefore implying also that their functional properties could also have a semblance. In this regard suggestions to increase the production of indigenous fowl for potential economic and health benefits of its egg (Oluwatade, 2009; Ajayi, 2010; Egahi et al, 2013) would thus be encouraging.

\section{Conclusion and recommendation}

Japanese quails Cortunix japonica, are raised intensively, in battery cages, and fed quail layer mash $(24 \% \mathrm{CP})$ at Songhai-Delta demonstration farm. Eggs laid are routinely collected in egg crates and sold at the Songhai Farm shop to wholesalers and retailers. Quail eggs are smaller than IDF egg in size, but they have similar shapes. The shell of quail egg is thin, more fragile and delicate than shell of IDF egg. Hence quail eggs require tender handling and extra care in storage. The relative weights of their structural components are similar; though the Haugh unit, albumen index and Yolk index values of quail egg are significantly higher than values for IDF eggs. The two sets of egg showed similar pattern in their proximate composition values; though quail egg contained higher levels of crude protein and lipids than IDF egg. The quail egg is reportedly a valuable functional and health food. This study recommends that based on the similarity of their characteristics the functional properties of IDF egg should be examined through research.

\section{References}

Ajayi, F. O. 2010. Nigerian indigenous chicken: a valuable genetic resource for meat and egg production. Asian Journal of Poultry Science, 4:164-172.

AOAC, 2010. Association of Official Analytical Chemist. Official Methods of Analysis, 20 $0^{\text {th }}$ edition, Washington, DC, USA.

Bain, M. M. 2005. Recent advantages in the assessment of egg shell quality and their future applications. World Poultry Science Journal, 61:268277.

Coutts, J. A. and Wilson, G. C. 1990. Egg Quality Handbook, Queensland Department of Primary Industries, Australia.

Dana, N., Van der Waaij, E. H. and Van Arendok, J. A. 2011. Genetic and phenotypic parameter estimates for 


\section{Odafe-Shalome and Owen}

body weights and egg production in Horro chicken of Ethiopia. Tropical Animal Health and Production: 43: 21-28.

De Ketelaere, B.; Barnelis, F.; Kemps, B.; D e c u p e r e, E. a nd D e Baerdemcker, J. 2004. Nondestructive measurements of the egg quality. World Poultry Science Journal, 60:2326-2333.

Egahi, J. O.; Dim, N. I. and Momoh, O. M. 2013. The effects of plumage modifier genes on egg quality indices of the Nigerian local chicken. Journal of Agric and Veterinary Science 2(2): 04-06.

Haugh, R. R. 1937. The Haugh unit for measuring egg quality. US Egg poultry magazine, 43:522-555, 572-673.

Horst, P. 1991. Native fowl as a reservoir for genomes and major genes with direct and indirect effects on the adaptability and their potential for tropically oriented breeding plans a review. Animal Research and Development 33: 63-79.

Jones, D. R. and Mushgrove, M.T. 2005. Effects of extended storage on egg quality factors, Poultry Science, 84:1774-1777.

Jones, D. R. 2007. Egg functionality and quality during long term storage, Int. Journal of Poultry Science, 6:157-162.

Keenar, K. M.; McAvoy, K. C.; Foegeing, J. B.; Curtis, P. A.; Anderson, K. E.; Osborne, J. A. 2006. Effects of testing temperature on internal egg quality measurement, Poultry Science, 85:550-555.

Kirunda, D. F. K.; McKee, S. R. 2000. Re lationship quality characteristics of aged and fresh eggs, Poultry Science, 79: 11891193

Mizutani, M. 2003. The Japanese Quail.
Laboratory Animal Research Station. Nippon Institute for Biological Science, Kobuchizawa, Yamanashi. $\mathrm{J}$ a $\mathrm{p}$ a $\mathrm{n}$. (http://www.angrin.tlri.Rov.tw/ape c2Q03/Chapter5JPQuail.pdf): $\mathrm{R}$ e $\mathrm{t}$ r i e $\mathrm{v}$ e d December 15, 2009.

Narushin, V. G. and Romnov, M. N. 2002. Eggs physical characteristics and hatchability, World Poultry Science, 58: 297-203.

Odafe Shalome, G.I.O. and Uwadiae, T.I. 2020. Anthropometry and Carcass characteritics of Quails, Coturnix japonica, reared in cages at Songhai Delta Demonstration Farms. University of Benin, BeninCity. Unpublished

Olomu, J. M. 2003. Poultry production: Chickens, Turkeys, Guinea fowls, Ducks and Geese. A Jackem publication, Benin-City, Nig.

Olomu, J. M. 2011. Feeds and feeding stuff. Monogastric Animal Nutrition. Principles and Practice. St. Jackson Publishers, $2^{\text {nd }}$ Edition. ISBN-978, Benin-City, Nig. 2011.

Oluwatade, P. O.; Ogara, W. O.; Okuthe, S. 0.; Muchemi, G.; Okoth, E.; Ondido, M. O. and Adhiambo, R. F. 2009. Assessing the productivity of Indigenous Chickens in an extensive management system in South Nyanza Kenya. Tropical Animal Health and Production. 42:283-288.

Randall, M. and Bolla, G. 2008. Raising Japanese Quail. State of New South Wales, Department of Primary Industies. Prime Fact 602, 2nd Edition.

Rankling, F. W.; Artin, A.; Lison, G. M.; Artin, D. and Nnabelle, M. A. 1998. Quail: An egg and meat production system.

Sahin, N.; Akdemir, F.; Orhan, C.; 
Kucuk, 0.; Hayirli, A. and Sarvn, K. 2008. Lycopene-enriched Quail egg as functional food for humans. Food Research International 41: 295-300.

Sakunthaladevi, K. and Reddy, P. M. 2004. Effect of strain on physical egg quality characteristics in white leghorn layers, Indian Journal of Poultry Science. 39: 190-192

Shim Kim Fah, 2005. Nutrition and Management of Japanese Quails in the Tropics. www.that quail place.com.
Silversides, F. G. and Budgell, K. 2004. The relationship among measures of egg albumen, height, $\mathrm{pH}$ and whipping volume, Poultry Science, 83: 1619-1623.

Tunsaringkarn, T.; Tungjaroenchai, V.; and Siriwong, W. 2013. Nutrient benefits of Quail (Coturnix coturnix japonica) eggs. International Journal of Scientific and Research publications. 3 (5). May 2013

Woodward, A.E.; Abplanalp, H.; Wilson, W.O. and Vohra, P. 1973. Japanese Quail Husbandry in the Laboratory, Dept. of Avian Sciences, Univ of California, Davis. 22 pp.

Received: $20^{\text {th }}$ August, 2020

Accepted: $28^{\text {th }}$ November, 2020 